ZalącZnIil

\title{
TEATR NA WODZIE. WODNY ŻYWIOL WE WSPÓŁCZESNYM TEATRZE POLSKIM
}

MONIKA KOSTASZUK-ROMANOWSKA

Wydział Filologiczny, Uniwersytet w Białymstoku

Faculty of Philology, University of Bialystok

mromanow@poczta.onet.pl

Wprowadzenie na scenę wody z pewnością nie jest często stosowanym zabiegiem teatralnym. I trudno się temu dziwić, bo przecież wykorzystanie tego środka teatralnej ekspresji znacząco podwyższa koszty produkcji przedstawienia. Gdy parę lat temu w Teatrze Wielkim w Warszawie szykowano premierę Latającego Holendra ${ }^{1}$ - słynnej „morskiej” opery Richarda Wagnera - w reżyserii Mariusza Trelińskiego, konieczne okazało się zbudowanie ogromnego basenu o wielkości 26 na 20 metrów. Miała się w nim gromadzić woda (autor scenografii wspominał nawet o 70 tysiącach litrów²), która w trakcie przedstawienia lała się z góry na scenę. Problem stanowiły i gabaryty zbiornika, i jego skuteczna izolacja. Podobno firma, która zaoferowała w przetargu najniższą kwotę, wyceniła wykonanie tej usługi na 900 tysięcy złotych. Ostatecznie basen zbudowano dużo taniej, siłami własnych pracowni ${ }^{3}$.

Z podobnym zadaniem musiała się wcześniej zmierzyć ekipa techniczna Teatru Dramatycznego w Warszawie przy przedstawieniu Krystiana Lupy Niedokończony utwór na aktora ${ }^{4}$. By na scenie pojawiło się zaplanowane przez

1 Premiera Latającego Holendra odbyła się w 2012 roku.

2 Zob. A.S. Dębowska, Wielka ulewa w operze, http://www.e-teatr.pl/pl/artykuly/135257,druk.html [dostęp: 10.02.17].

3 Zob. A.S. Dębowska, Robia niesamowite rzeczy. Poznajcie ludzi Teatru Wielkiego w Warszawie, 2014, http://warszawa.wyborcza.pl/warszawa/1,34889,16779121,Robia_niesamowite_rzeczy__Poznajcie_ludzi_Teatru_ Wielkiego.html [dostęp: 10.02.17].

4 Przedstawienie miało premierę w 2004 roku. 
reżysera jezioro, trzeba było zamówić ekspertyzę oceniającą wytrzymałość podłogi. Najgłębsze miejsce zbiornika (dochodzące do półtora metra) musiało być podtrzymywane przez sześć metalowych słupów ${ }^{5}$. Aktor, który w jednej ze scen miał się w wodzie całkowicie zanurzyć, opowiadał o swoich przeżyciach na próbach tak:

Kiedy jestem w środku przedstawienia, zapominam, że to sztuczny zbiornik wodny. Mam wrażenie, że mamy przyjemny letni wieczór, a ja kąpię się w ciepłym jeziorze. [...] Reżyser chce, aby kąpiel Jakuba [postać $\mathrm{z}$ dramatu przyp. M.K.-R.] w jeziorze nie była tylko ilustracją do tekstu, ale mówiła coś więcej. Żeby pokazała piękno teatru, jego magię, a jednocześnie jego niedoskonałość. Stać nas na to, żeby wyczarować jezioro w teatrze, a jednak nigdy nie będzie to prawdziwe jezioro, najwyżej zalany teatr ${ }^{6}$.

Zacytowałam tę nieco przewrotną wypowiedź, bo dobrze oddaje ambiwalentny charakter wody jako elementu widowiska teatralnego. Woda to bardzo szczególne tworzywo sceniczne. Wydaje się, że w większym stopniu niż inne identyfikuje samą istotę teatralności, która polega przecież na nieustannym oscylowaniu między iluzją a realnością. Fizyczność wprowadzonej na scenę wody nie pozwala zapomnieć o dychotomii sztucznej scenicznej kreacji i materialnej dosłowności tworzywa. Oczywiście, wszystkie postacie wodnych żywiołów - morze, deszcz, burzę - można skutecznie artykułować przy pomocy całej palety ekwiwalentów, czyli światła, barwy czy dźwięku. Takich właśnie środków użył Robert Wilson w zjawiskowym, poetyckim spektaklu Kobieta $z$ morza ${ }^{7}$. Tę liryczną opowieść, wywiedzioną ze skandynawskich legend, reżyser wpisał w wysublimowaną, ascetyczną przestrzeń wypełnioną morskimi odgłosami, efektami świetlnymi i wydobywanymi światłem, zalewającymi scenę kolorami.

A jednak efekt wody, nie tej metaforycznej, lecz prawdziwej - tak bardzo limitowany ograniczeniami technicznymi (o czym była już mowa), i w konsekwencji zawsze jednak do pewnego stopnia sztuczny - ma nad wspomnianymi ekwiwalentami jedną zdecydowaną przewagę. Tą przewagą jest

${ }^{5}$ Zob. D. Wyżyńska, Zalana scena, http://www.e-teatr.pl/pl/artykuly/18758. html [dostęp: 10.02.17].

6 Wypowiedź Michała Sieczkowskiego, [cyt. za:] ibidem.

7 Spektakl miał premierę w Teatrze Dramatycznym w Warszawie w 2005 roku. 

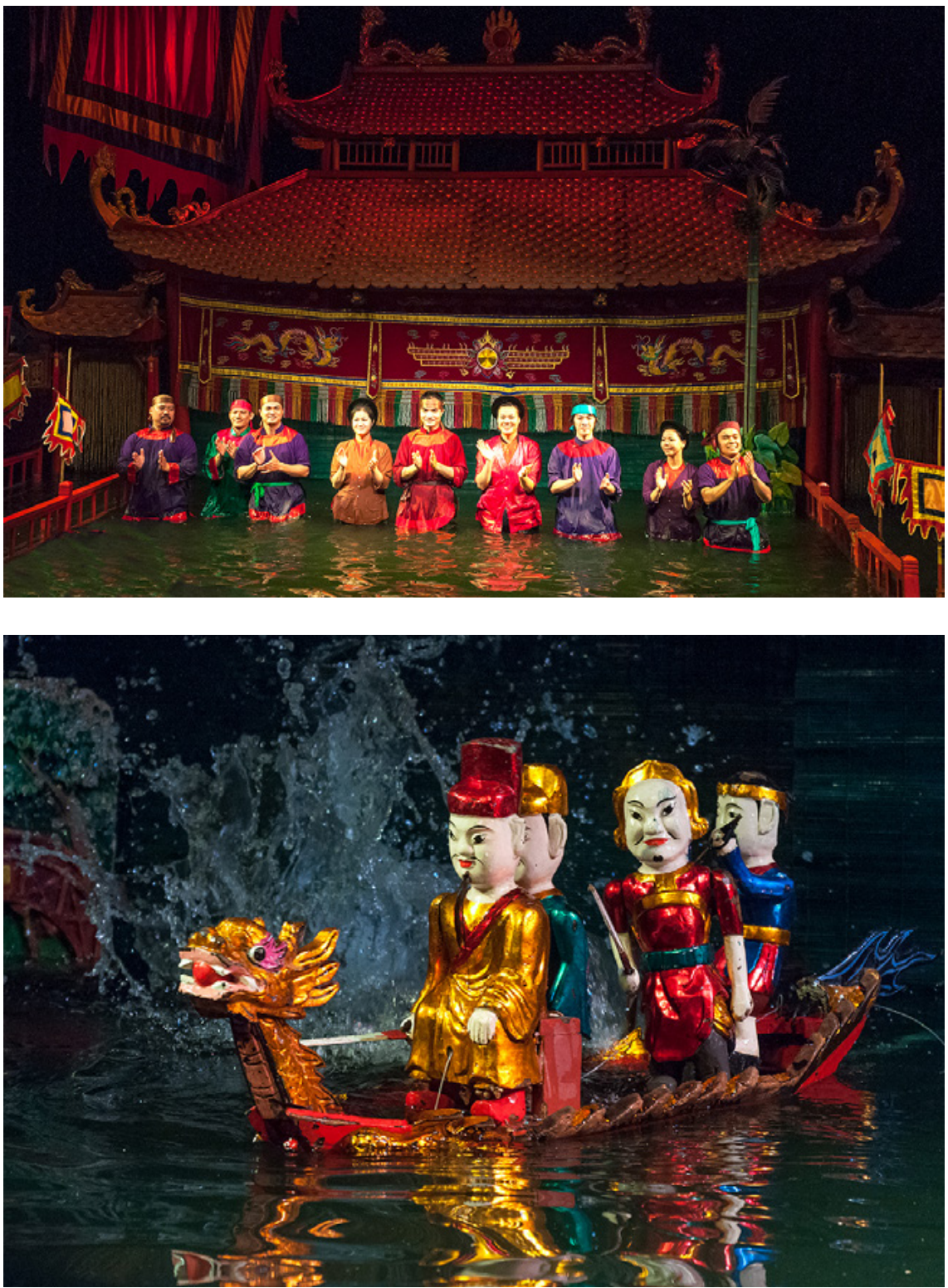

Il. 1-2. Wietnamski teatr lalek na wodzie, fot. Alicja Rapsiewicz (LosWiaheros.pl) 
trudny do zastąpienia potencjał widowiskowy. Można się o nim przekonać, obserwując występy teatrów grających... wyłącznie w/na wodzie, dla których woda to nie tylko środek sceniczny, ale przede wszystkim wyznacznik gatunkowy, świadomie stosowana konwencja. Wykorzystuje ją na przykład tradycyjny wietnamski teatr lalek na wodzie, notabene jedna z głównych atrakcji turystycznych Hanoi. Niezwykłość tych widowisk przybliża opis Đàm Vân Anh:

Już ponad tysiąc lat temu mieszkańcy delty Mekongu, uprawiając [...] ryż, dostrzegli potencjał, jaki tkwił w żywiole wody nie tylko jako podstawy do uprawy, ale również sceny, na której można odtwarzać ludowe opowieści i legendy. [...] Woda świetnie ukrywała ramiona poruszające kukiełkami i umożliwiała stworzenie dodatkowych, ekscytujących efektów jak wzburzone fale i tryskające w górę strumienie. [...] Sceną dla przedstawień wodnego teatru jest obecnie konstrukcja mająca postać basenu o powierzchni około 4 metrów kwadratowych. Za bambusową makietą odzwierciedlającą front typowej wietnamskiej świątyni kryje się nawet do ośmiu aktorów, którzy poruszając specjalnymi prętami, ożywiają lalki do nich przyczepione. [...] Kukiełki pojawiają się na wodnej scenie, wysuwając się z dwóch stron makiety ukrywającej aktorów lub, ku uciesze widzów, witają ich, wynurzając się niespodziewanie $\mathrm{z}$ wody ${ }^{8}$.

Oryginalny gatunek wietnamskiego teatru lalek na wodzie wywodzi się z lokalnej tradycji ludowej sięgającej XI wieku. Przykładem współczesnego modelu widowiska granego w wodzie są natomiast przedstawienia francuskiej grupy Ilotopie. Sami twórcy deklarują, że w ich praktykach „woda jest nową dziedziną współczesnego doświadczenia teatru" ", doświadczenia wykorzystującego swoistą „energię” żywiołu. Polska publiczność miała okazję zobaczyć efektowne spektakle zespołu. W 2001 roku przedstawienie Narcisse quette $\mathrm{z}$ repertuaru Ilotopie włączono do programu XI Międzynarodowego Festiwalu Teatralnego „Malta” w Poznaniu. „Wodną” koncepcję widowiska - nawiązującą do mitologicznej historii Narcyza - reżyserka Dominique

8 Đ. Vân Anh, W wodzie po kostki: wietnamski teatr lalek wodnych, http:// kontynent-warszawa.pl/felietony/kulturalia/762-w-wodzie-po-kostki-wietnamski-teatr-lalek-wodnych [dostęp: 11.02.17].

9 Zob. Spectacles sur l'eau, http://ilotopie.com/spectacles/?lang=fr [dostęp: 12.02.17]. Tłumaczenie własne. 


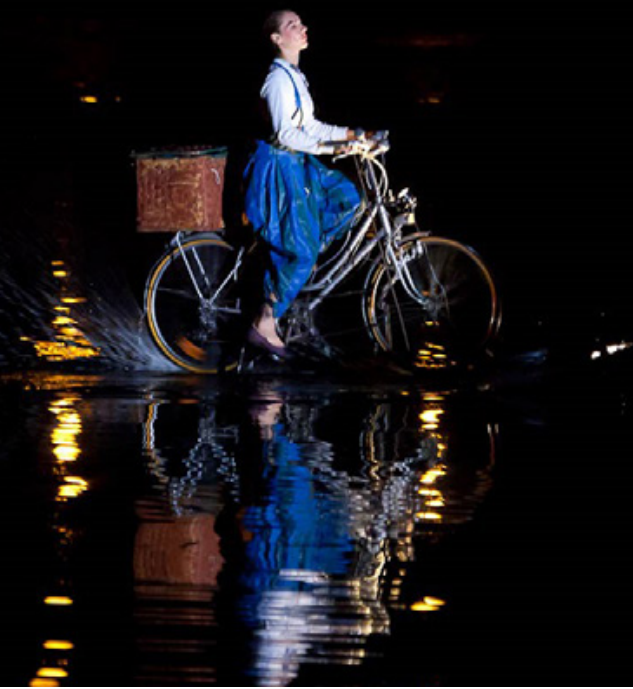

$\frac{1}{8}$
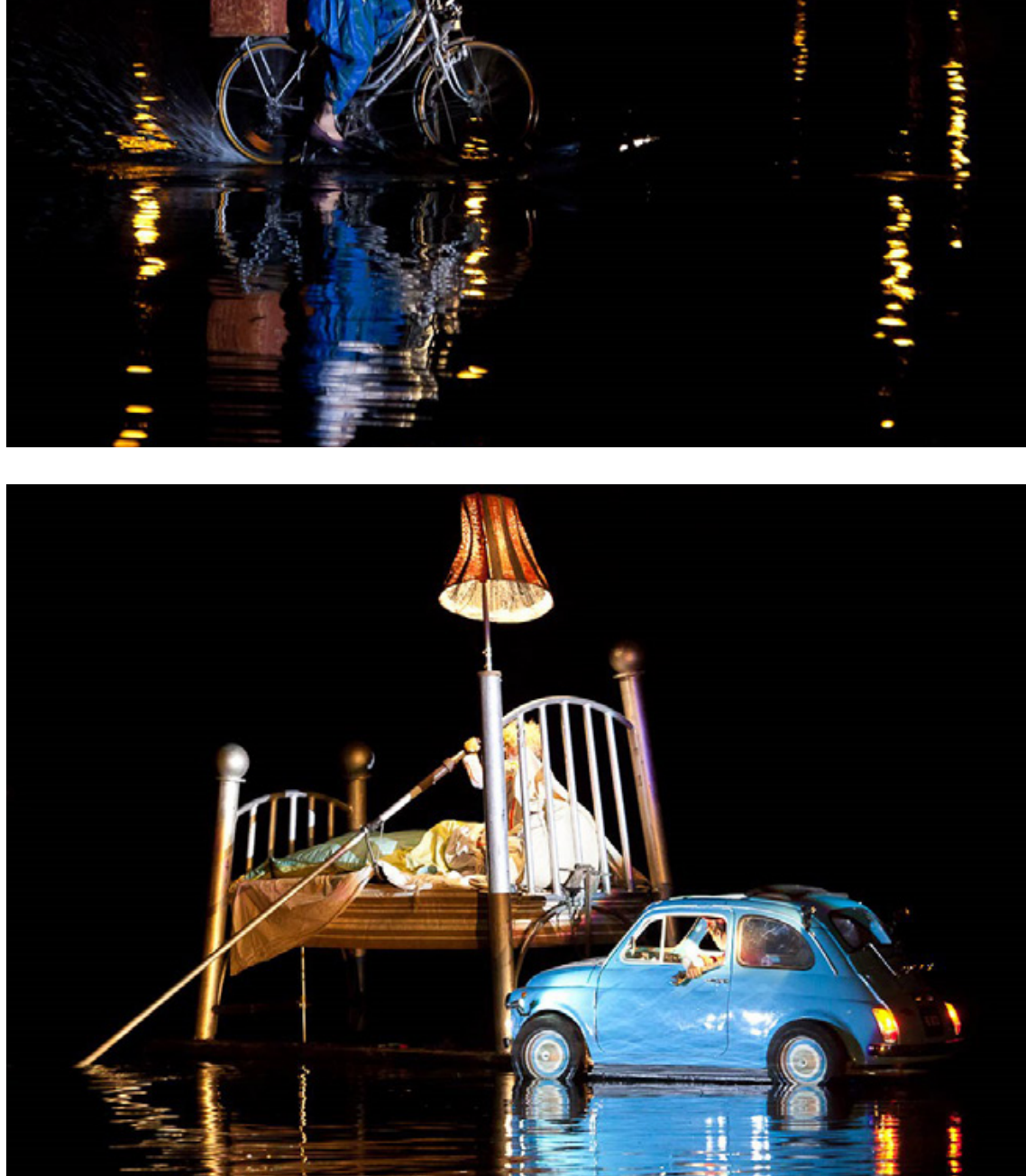

Il. 3-4. Fous de Bassin, Compagnie Ilotopie, fot. Tomasz Tarnowski 
Noël objaśniała następująco: „Pierwszym zwierciadłem człowieka była woda, i dlatego nasze przedstawienie o micie Narcyza chcemy przedstawić na wodzie. Będzie to gra iluzji i odbić lustrzanych"10. Z kolei w trakcie XV edycji Międzynarodowego Festiwalu Teatrów Plenerowych i Ulicznych FETA w Gdańsku w 2011 roku zespół przedstawił spektakl Water fools. Przygotowane $\mathrm{z}$ wielkim rozmachem widowisko było jednym $\mathrm{z}$ najdroższych wśród prezentowanych podczas dotychczasowych edycji festiwalu. Rozpoczynała je scena z przejeżdżającym po wodzie samochodem, potem pojawiał się też pedałujący rowerzysta, „żeglujące” łóżko, płynący po wodzie sprzątacz z miotłą i pojemnikiem na śmieci oraz kobieta z dziecięcym wózkiem. Niezwykła sceneria wydobywała z sekwencji zwykłych, codziennych zachowań nowy, metaforyczny sens. Woda - jak można było przeczytać $\mathrm{w}$ opisie przedstawienia - pełniła w nich rolę „czynnika ujawniającego kruchość ludzkiej kondycji”"11.

Niekwestionowalnym atrybutem wielkich widowisk plenerowych jest możliwość włączenia do spektaklu rzeczywistego akwenu. Stanowią one jednak odrębny, rządzący się własnymi prawami gatunek. W klasycznym teatrze repertuarowym, zlokalizowanym w budynku i niedysponującym taką możliwością, woda pojawia się w odmiennych, ale równie interesujących wariantach i konfiguracjach scenograficznych. Gdyby posłużyć się stricte technicznymi kategoriami ilości i typu źródła, należałoby sklasyfikować trzy najczęściej stosowane odmiany. Pierwsza polega na wykorzystaniu stosunkowo ograniczonej ilości wody wylewanej z kranu, węża lub naczynia. Wariant drugi to umieszczanie na scenie mniejszych i większych zbiorników wodnych lub całych basenów. Ostatni model wprowadza efekt wody spadającej z góry i zalewającej scenę.

W przypadku wariantu pierwszego, wykorzystującego wodę jako pojedynczy znak teatralny, symbolika takiego znaku okazuje się szczególnie gęsta właśnie dlatego, że dotyczy jedynie drobnego komponentu akcji scenicznej.

${ }^{10}$ Cyt. za: „Malta” rusza już XI raz, https://www.wprost.pl/kultura/15837/ Malta-rusza-juz-XI-raz.html [dostęp: 12.02.17].

${ }^{11}$ Zob. «Fous de bassins» na zamknięcie festiwalu FETA w Gdańsku, http://www. institutfrancais.pl/pl/evs/fous-de-bassins-na-zamkniecie-festiwalu-feta-w-gdansku [dostęp: 12.02.17]. 
Trudno więc odmówić mu, istotnego dla znaczeń spektaklu, „wyposażenia” semiotycznego. Jednak w odniesieniu do tego typu zabiegów nie ma zastosowania zasada umownie opisana formułą „teatru na wodzie”. Ponieważ pojedynczy element akwatyczny nie stanowi motywu dominującego, nie może być potraktowany jako strategia - scenograficznie i semantycznie identyfikująca całość komunikatu scenicznego. Ale, co warto zauważyć, tego typu znak teatralny jest z pewnością znakiem szczególnym w tym znaczeniu, że jego sztuczność wydaje się stosunkowo najmniej „sztuczna”. W odbiorze widzów iluzja „prawdziwej” wody, na przykład wylanej z kubka na scenie - w przeciwieństwie choćby do wody wylewanej litrami w postaci deszczu - pozostaje, co oczywiste, iluzją pełną. Nie zakłóca jej wrażenie (opisane w zacytowanej powyżej wypowiedzi aktora z przedstawienia Lupy) obcowania z efektem „sfabrykowanym”, będącym stricte teatralną kreacją.

Przywołam na zasadzie ilustracji tylko dwie takie sceny, pozornie podobne, a jednak w swej wymowie biegunowo przeciwne. Pierwszy przykład to monolog księdza Piotra z przedstawienia Mickiewicz. Dziady. Performance Pawła Wodzińskiego ${ }^{12}$. W scenerii przypominającej raczej noclegownię niż więzienie polskich patriotów chluśnięcie wodą (wylaną prosto $\mathrm{z}$ metalowego kubka) w twarz punktowało wizjonerską opowieść o sądzeniu i dręczeniu Chrystusa, czyli Polski - miało więc mesjański, oczyszczający sens. Z kolei w legendarnej inscenizacji 2007: Macbeth Grzegorza Jarzyny ${ }^{13}$, zrealizowanej w postindustrialnych wnętrzach nieistniejącej już Zakładów Waryńskiego na warszawskiej Woli, mocnym akcentem była scena polewania przez Lady Macbeth wodą ze szlaucha posadzki unurzanej we krwi. U Jarzyny woda zestawiona $\mathrm{z}$ krwią nie była - jak w spektaklu Wodzińskiego - ani cucąca, ani oczyszczająca - została wpisana w krąg zbrodni, intrygi, wojny i śmierci.

Kategoria pierwsza - nazwijmy ją „wariantem minimalistycznym” oznacza zatem kreowanie dosyć wyrazistych (by nie powiedzieć: przewidywalnych) znaków scenicznych. Jednak w kontekście omawianego tematu ważniejsze wydają się realizacje, których twórcy zdecydowali się na rozwiązania „wielkogabarytowe” i wprowadzili na scenę spore ilości wody,

12 Premiera spektaklu odbyła w Teatrze Polskim w Bydgoszczy w 2011 roku.

13 Spektakl wystawiony przez TR Warszawa w 2005 roku. 
organizując przy pomocy tego zabiegu przestrzeń gry najczęściej (i „z konieczności”) w całym spektaklu.

Zacznę od przykładu nietypowego w tym sensie, że wspomniany zbiornik nie musiał być na scenie budowany, gdyż reżyser posłużył się przestrzenią gotową, która takim obiektem dysponowała. W spektaklu $H$. Jana Klaty ${ }^{14}$, bo o nim mowa, zastosowano strategię właściwą wspomnianemu już gatunkowi widowiska plenerowego. Przedstawienie zrealizowano, podobnie jak Macbetha Jarzyny, w scenerii postindustrialnej ${ }^{15}$. Taki „naturalny” plener stanowił teren zrujnowanej Stoczni Gdańskiej. Dopisaną Szekspirowi scenę samobójstwa Ofelii (a właściwie scenę wyławiania jej ciała) rozegrano w basenie portowym. Oczywiście, w teatrze ma znaczenie, czy o śmierci Ofelii widzowie dowiadują się - jak u Szekspira - z wypowiedzi Królowej, czy też sami mogą wejść w rolę ciekawskich gapiów, którzy gromadzą się nad brzegiem basenu i mimo że stoją za policyjną taśmą, to jednak na własne oczy śledzą akcję wyławiania zwłok, a następnie zamykania ich w czarny foliowy worek. Akcję, dodajmy, jakby żywcem przeniesioną z kronik kryminalnych. To właśnie ta stylizacja brutalnie dekonstruowała ewentualne nawiązania do obrazów Eugène’a Delacroix czy Johna Everetta Millaisa, choć przez moment upozowanie martwej Ofelii, nieruchomo leżącej na wodzie, wyraźnie przywodziło skojarzenia z tym drugim dziełem.

Figura Ofelii - topielicy, która „wodzie oddała swoje młode życie” z pewnością natomiast stanowiła inspirację dla autorek innego spektaklu wystawionego w Teatrze Polskim w Bydgoszczy Przyrzecza ${ }^{16}$. Muzyczny monodram osnuto na fragmentach dziennika Virginii Woolf ${ }^{17}$, która, przypomnijmy, popełniła samobójstwo, skacząc do rzeki. Choć przedstawienie zrealizowano „tradycyjnie”, to proponowało ono zdecydowanie „nietrady-

${ }^{14}$ Spektakl według Hamleta przygotowany przez Teatr Wybrzeże w Gdańsku w 2004 roku.

15 Oba spektakle analizowałam w tekście Szekspir postindustrialny zamieszczonym w: Szekspir wśród znaków kultury polskiej, red. E. Łubieniewska, K. Latawiec, J. Waligóra, Kraków 2012.

16 Premiera odbyła się w 2012 roku. Autorkami konceptu przedstawienia były Agata Skwarczyńska, Aneta Jankowska i grająca w spektaklu Karolina Adamczyk.

17 Obok dzienników Virginii Woolf inspiracją dla autorek były też teksty piosenek brytyjskiej wokalistki PJ Harvey. 
cyjne" rozwiązania scenograficzne. W bydgoskiej inscenizacji pojawiało się bowiem duże akwarium o wielofunkcyjnym, jak się okazało, zastosowaniu:

Rewelacyjny pomysł na scenografię - prostopadłościan wypełniony wodą jest dla głównej postaci niezwykle atrakcyjny pod wieloma względami. Raz jest źródłem dźwięków, odwołując się do siły natury tak bliskiej kobiecie, kiedy indziej staje się przestrzenią, do której boi się [ona] wejść, stojąc na krawędzi, przyglądając się ze strachem i zainteresowaniem, przywołującą skojarzenia z próbą samobójczą. Czasem też stanowi miejsce infantylnych zabaw, unaoczniając piękno rozwoju człowieka $\mathrm{z}$ radosnego dziecka po zmysłową kobietę ${ }^{18}$.

„Ogrywanie” elementów scenograficznych zalicza się do podstawowego repertuaru środków aktorskich. W przypadku Przyrzecza dość szczególny obiekt umieszczony w planie gry był jednocześnie wykorzystywanym przez aktorkę instrumentem - instrumentem, dodajmy, także w znaczeniu dosłownym. „Woda kusi i każe ryzykować” - pisał Szymon Spichalski ${ }^{19}$. Bohaterka eksperymentowała więc z materią wody - dotykała jej, wskakiwała do niej, zanurzała się. Dźwięki wydobywane $z$ wody w trakcie tych działań oddawał umieszczony wewnątrz akwarium mikrofon. „Penetracja” wody, już sama w sobie widowiskowa, faktycznie stawała się - co zostało podkreślone w cytowanej wcześniej recenzji - metaforą stanu psychicznego bohaterki. Wśród wielu sensów tej metafory jeden wydawał się szczególnie mroczny. Wyrażał - można to tak ująć - stopniowe zamykanie się bohaterki w neurotycznym świecie własnej psychiki. W nim, jak pod wodą, unieważnione zostaje całe - istniejące ponad taflą - życie. Optycznie zmieniona postać, którą widzowie mogli obserwować przez ściany akwarium, momentami rzeczywiście przypominała topielicę. Jednocześnie wielowymiarowo eksploatowany żywioł wody ostatecznie pozostawał żywiołem nieodgadnionym, dającym możliwość różnych, sprzecznych, ale i komplementarnych, odczytań.

18 P. Blanca, Nie ma historii, jest akcja [recenzja spektaklu „Przyrzecze”], http:// bydgoszcz.naszemiasto.pl/artykul/nie-ma-historii-jest-akcja-recenzja-spektaklu -przyrzecze,3158757,art,t,id,tm.html [dostęp: 14.02.17].

19 S. Spichalski, Adamczyk stapa po wodzie, http://www.e-teatr.pl/pl/artykuly/139203.html [dostęp: 15.02.17]. 
Autorki projektu - zauważyła Agnieszka Serlikowska - wspominały w zapowiedziach o alegorycznym motywie topielicy Ofelii, o podjęciu próby zbadania tajemnicy zatonięcia kobiety. Według mnie rzeka nie musi wiązać się ze śmiercią we wszystkich historiach przedstawionych w spektaklu. Może być także symbolem kobiecego wyzwolenia, poznania świata czy egzystencjalnego spokoju ${ }^{20}$.

Spektakl Przyrzecze stanowił ciekawy przykład teatralnej eksploracji wody - odkrywania jej materialnej faktury, udźwięczniania, pobudzania jej wielozmysłowego potencjału. $Z$ takim efektem mamy do czynienia wówczas, gdy woda w spektaklu pojawia się jako sceniczny partner aktora. To oczywiście tylko jedno z możliwych zastosowań motywu akwatycznego, które sprawdza się zwłaszcza w spektaklach skupionych, kameralnych, próbujących się zmierzyć z tajemnicą ludzkiej psychiki.

Wprowadzanie na scenę obiektów wodnych jest zawsze, co pokazał też spektakl Przyrzecze, działaniem o charakterze proksemicznym. Tafle wody, co oczywiste, nadbudowują plan gry, wyposażają sceniczną przestrzeń w dodatkowy wymiar. Stają się też quasi-naturalnymi ekranami - wchłaniają światła i barwy, odbijają sylwetki postaci. Strukturyzują, a jednocześnie waloryzują plastyczną kompozycję sceny. Tego typu efekt wykorzystano w inscenizacji Szekspirowskiego dramatu Antoniusz i Kleopatra przez Wojciecha Farugę $^{21}$ - dosyć brutalnym spektaklu z interesującą, minimalistyczną scenografią. Jeden z recenzentów, Piotr Olkusz, opisał ją następująco:

Wizualnie to bardzo ładny spektakl. Wielka rampa falujących pagórków schodzi delikatnie w stronę widowni, trafiając po drodze na spory basen z wodą. Patrzymy na czarną Afrykę za morzem. Dosłownie czarną, bo piasek, zamiast skrzyć się złotem, wygląda, jakby próbowano go zasmołować ${ }^{22}$.

Zastosowany przez twórców element wodny faktycznie zdawał się kontrastować z księżycowym krajobrazem lądu. Lecz oba motywy nie budowały prostej opozycji. Martwocie ziemi nie przeciwstawiał się życiodajny żywioł

20 A. Serlikowska, Wodą i dźwiękiem o...?, http://www.e-teatr.pl/pl/artykuly/138640,druk.html [dostęp: 15.02.17].

${ }^{21}$ Spektakl wystawiono w Teatrze im. Stefana Jaracza w Łodzi w 2016 roku.

${ }_{22}$ P. Olkusz, Dlaczego nie po prostu?, http://teatralny.pl/recenzje/dlaczegonie-po-prostu,1389.html [dostęp: 16.02.17]. 

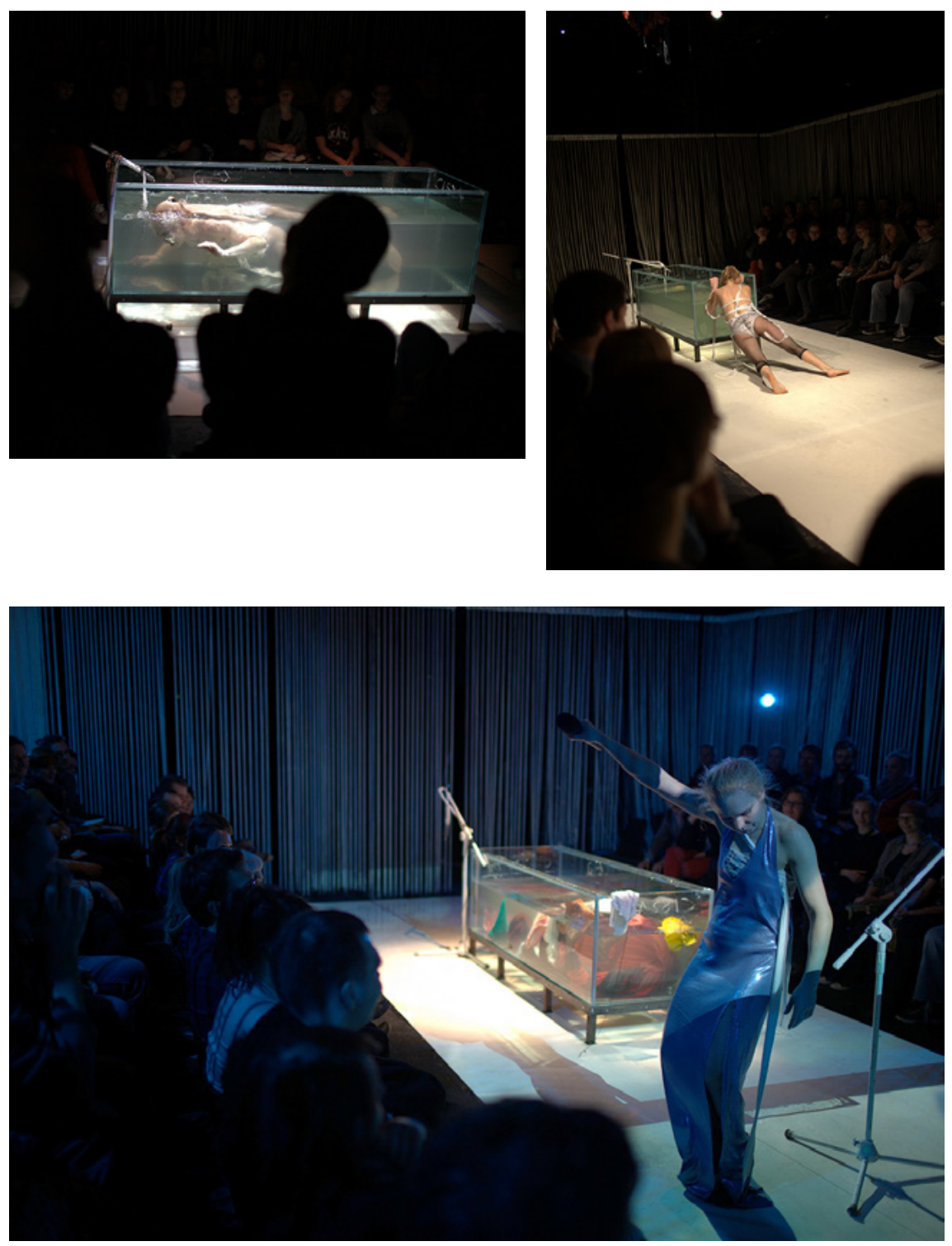

Il. 5-7. Przyrzecze (Teatr Polski im. H. Konieczki w Bydgoszczy, koncept: Agata Skwarczyńska, Aneta Jankowska, Karolina Adamczyk), fot. Paulina Stranz 
wody. Woda na scenie budziła skojarzenia z morzem, ale też z Nilem. Tyle że nie wydawał się on rzeką - co słusznie zauważyła Anna Tomasiewicz „która buntuje się przeciwko własnym brzegom, by dać zalążek nowego życia"23. Element wodny - zrealizowany w postaci długiego, zwieńczającego front sceny, kanału - podkreślał raczej niż negował wrażenie martwoty wpisane w całość wizji scenograficznej. Sugerował, jak przekonywała recenzentka, że „hellenistyczne królestwo to ziemia jałowa” ${ }^{24}$. W pewnym sensie ów symboliczny „Nil” stawał się więc rzeką śmierci. Wskazywała na to zwłaszcza jedna ze scen przedstawiająca metaforyczny obraz bitwy pod Akcjum. Użyto w niej ciekawego rozwiązania polegającego na połączeniu dwóch żywiołów, wody i ognia - po wodzie poruszały się, malowniczo płonąc, podpalone palnikiem tlenowym małe papierowe okręty.

Ruch (wody i w wodzie) - naturalny atrybut żywiołu - w teatrze staje się oczywistym środkiem ekspresji dynamizującym kompozycję przestrzenną. Modelowanie planu scenicznego przy użyciu motywów wodnych ma zatem charakter - jak to określa Jerzy Limon - „chronotypowy”25. Pojęciem tym badacz opisuje jeden $\mathrm{z}$ wariantów kształtowania przestrzeni w spektaklu. Na plan scenografii nakłada się akcja, a wraz z nią ruch sceniczny i gesty wykonywane przez postacie. Zmienność, cechująca dramaturgię opowiadanej w spektaklu historii, nie jest jedynie rozwojem w czasie - może dotyczyć również wymiaru przestrzennego. Nie chodzi tu o oczywisty zabieg zmiany dekoracji, lecz o wpisaną weń, silnie powiązaną z akcją, dynamiczność. Taką zdynamizowaną scenografię określa Limon własnym (a dokładniej: przeniesionym z literaturoznawstwa) terminem „chronografia”:

Za chronografię będę zatem uważał te dzieła sceniczne, w których zmienność kompozycji scenograficznej (również i tej budowanej światłem) jest nie tylko tłem, ale istotnym elementem akcji i odbywa się w obrębie jednej sceny (to znaczy nie tylko jako zmiana dekoracji pomiędzy scenami czy aktami). Ukazywane na oczach widzów zmiany w scenografii (już: chronografii) są powiązane $\mathrm{z}$ wydarzeniami na scenie albo same te wydarzenia tworzą.

23 A. Tomasiewicz, Historia troszkę splamiona nieszczęściem, http://www. teatrdlawas.pl/recenzje/5283-historia-troszke-splamiona-nieszczesciem [dostęp: 16.02.17].

24 Ibidem.

25 Zob. J. Limon, Piąty wymiar teatru, Gdańsk 2006, s. 181. 
Inaczej mówiąc, jest to szczególny wypadek, kiedy scenografia „gra” również w sensie ruchowym ${ }^{26}$.

Wydaje się, że zastosowanie w inscenizacji motywu akwatycznego nie tylko umożliwia, ale wręcz gwarantuje wspomniany efekt. Woda jako żywioł implikuje ruch, zmienność, właściwą jej naturze dynamikę. Woda zgromadzona na scenie - oczywiście, w odpowiednio dużej ilości - z racji samej swej natury dysponuje potencjałem ruchu i zmienności. Oferując możliwość kreowania - z użyciem barwy i światła - coraz to nowych jakości wizualnych (ale przecież też dźwiękowych), tworzy własne przebiegi zdarzeń. A jednocześnie stymuluje właściwą akcję sceniczną. „Gra”, wchodzi w rolę szczególnego nad-aktora, a także prowokuje, wymusza wręcz działania „żywych” aktorów.

I tu pojawia się problem - motyw, który może być atutem inscenizacji, może też okazać się jej słabością. Reżyser, decydując się na wykorzystanie wody w spektaklu, nie zawsze ma dobry pomysł na to, co i dlaczego ma $z$ tą wodą (a częściej: w wodzie) robić aktor. W łódzkim spektaklu woda stanowiła na przykład oczywisty kontekst scen erotycznych. Lecz nie wszystkie „akcje wodne” wydawały się równie przekonująco umotywowane. Wskazuje na to wypowiedź jednej z recenzentek: „ten element scenografii byłby naprawdę dobrym pomysłem, gdyby nie fakt, że większość epizodów z jego wykorzystaniem opiera się na bezcelowym i nieuzasadnionym wskakiwaniu do wody" ${ }^{27}$. Z kolei cytowany już Olkusz kończył swój opis scenografii następującą refleksją: „Obraz ładny. Przypuszczam jednak, że Wojciech Faruga nie reżyserował Antoniusza i Kleopatry po to, by pierwszą rzeczą, która przyjdzie widzowi do głowy na myśl o tym spektaklu, była plastyka"28.

Podobnych zarzutów nie uniknął też spektakl, o którym wspomniałam na początku. Twórcy Latającego Holendra dość precyzyjnie objaśniali koncepcję inscenizacji. Autor scenografii, Boris Kudlička, tłumaczył: „Chodziło mi o stworzenie wrażenia czarnej otchłani, głębiny" ${ }^{29}$. Inspiracją były

${ }^{26}$ Ibidem, s. 256.

27 I. Herłazińska, Na początku i na końcu był chaos, http://www.teatrdlawas. pl/recenzje/4959-na-poczatku-i-na-koncu-byl-chaos [dostęp: 16.02.17].

28 P. Olkusz, op. cit.

${ }^{29}$ Cyt. za: A.S. Dębowska, op. cit. 

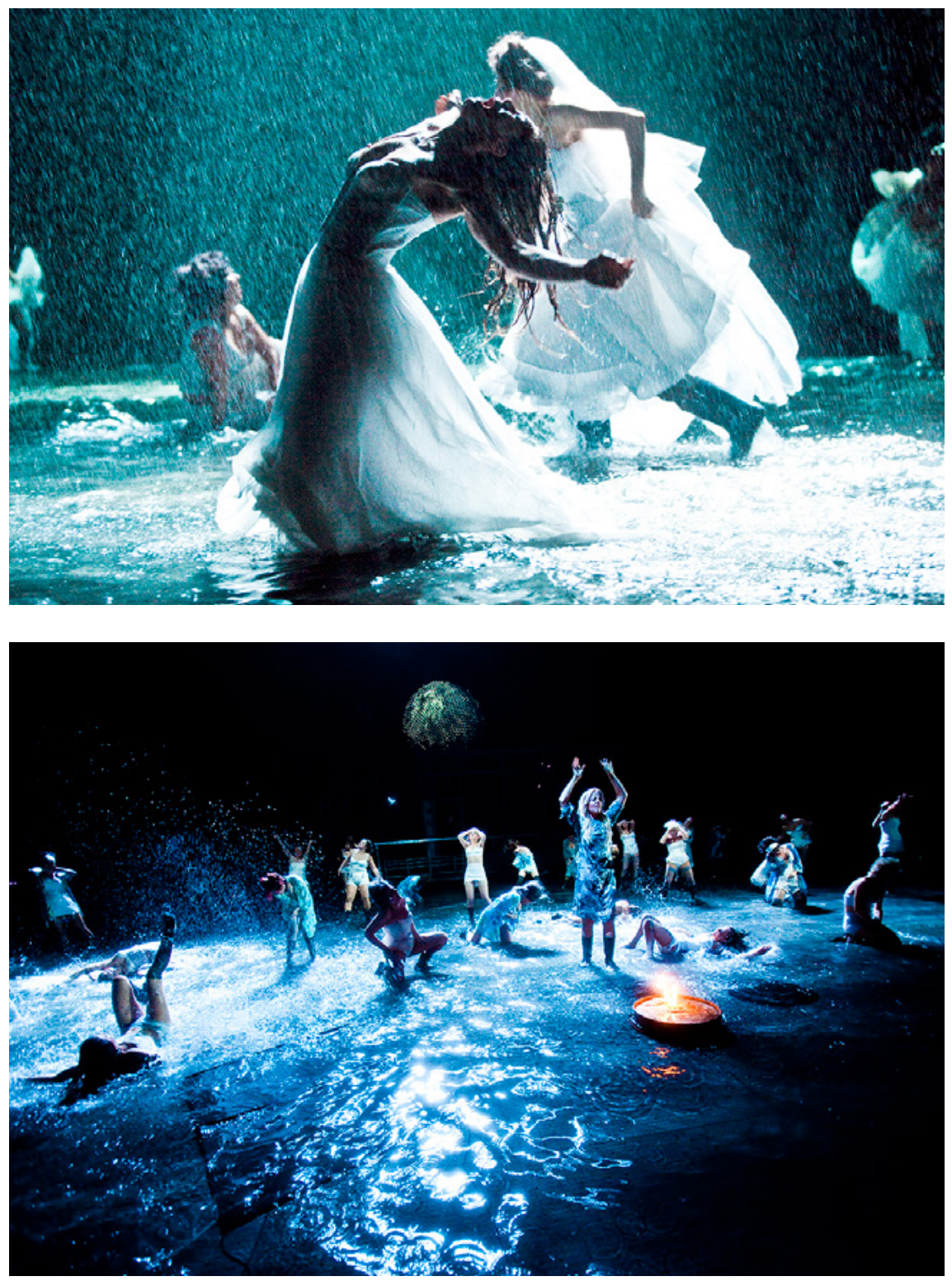

Il. 12-13. Latający Holender (Teatr Wielki - Opera Narodowa, reż. Mariusz Treliński), fot. Krzysztof Bieliński 
autentyczne kataklizmy - tsunami i powodzie ${ }^{30}$. Sam Wagner, jak wiadomo, napisał swoją operę pod wpływem dramatycznego przeżycia - sztormu na Morzu Północnym. Na scenie Teatru Wielkiego faktycznie udało się wyczarować - choć wydawało się to niemal niemożliwe ${ }^{31}$ - wizję bezkresnego oceanu, prawdziwego mare tenebrarum. Wzmacniały ją zwielokrotnione, nakładające się na siebie obrazy wody. Widzowie mogli obserwować przecinające się powierzchnie deszczu, rozbryzgiwane tafle wody i snujące się opary mgły. Mroczna scenografia wyrażała symbolikę samotności, cierpienia i śmierci.

Zjawiskowe obrazy stworzone przez Kudličkę spotkały się z uznaniem krytyków, którzy docenili ich estetyczną maestrię, ekspresyjną siłę i konsekwentnie budowany, metaforyczny przekaz.

To właśnie mrok, światło i woda - podkreślał Olgierd Pisarenko - wspaniale organizują przestrzeń dramatu przez opalizujące, chłodne barwy i ruchome faktury, budowane z mgły, pyłu wodnego, kropli i strug deszczu, rozprysków i odblasków na falującej, czarnej tafli wody. Świat cieśnin i fiordów Północy, wykreowany na scenie Opery Narodowej, wydaje się nieprzytulny, zimny i abstrakcyjny, ale obrazy te mają zarazem fascynującą, nostalgiczną urodę i coś z atmosfery czarno-białych ekspresjonistycznych filmów z lat dwudziestych ${ }^{32}$.

Sam pomysł wprowadzenia na scenę hektolitrów wody w przypadku tego akurat dzieła nie budził wątpliwości. Pojawiły się jednak wypowiedzi kwestionujące nie tyle zasadność użycia „morskiej” scenografii, ile jej rolę w budowaniu dramaturgii spektaklu. Twórcom zarzucano, że nadmiernie poddali się "logistyce wody”33, która - jak pisano - „skradła spektakl”34,

${ }^{30}$ Zob. ibidem.

${ }^{31}$ Sam Kudlička przyznał: „W trakcie realizacji tego pomysłu poruszałem się na granicy możliwości technicznych”. Ibidem.

32 O. Pisarenko, Mokra robota. Latający Holender w Operze Narodowej, http://www. ruchmuzyczny.pl/PelnyArtykul.php?Id=2067 [dostęp: 17.02.17].

33 J. Hawryluk, „Latający Holender” Trelińskiego. Trafiony, zatopiony, http://wyborcza.pl/1,75410,11372269,__Latajacy_Holender_Trelinskiego_Trafiony_zatopiony. html [dostęp: 17.02.17].

34 L. Raś, „Latający Holender” dopłynął do Teatru Wielkiego Opery Narodowej, http://www.wiadomosci24.pl/artykul/latajacy_holender_ 
zdominowała inscenizację, podporządkowała ją sobie, ale nie udźwignęła wszystkich jej sensów. Jacek Hawryluk mówił wręcz o „utopieniu” koncepcji, dodając, że „żaden z elementów scenografii nie wchodzi z wodą w dialog, a jeśli już się stara, to raczej jej "przeszkadza«" ${ }^{35}$. Podobne wrażenia mieli zapewne też inni komentatorzy (zresztą, tak jak Hawryluk, na ogół doceniający walory estetyczne spektaklu). Świadczyły o tym choćby już same tytuły recenzji - Mokra robota, Wodochciejstwo czy Aquapark na scenie ${ }^{36}$.

Inscenizacja Trelińskiego pokazała, że żywioł wody jest w teatrze wyjątkowo atrakcyjnym, ale i skrajnie trudnym tworzywem. Notabene, to właśnie jego atrakcyjność przesądza o jego problematyczności. Niesie bowiem ze sobą ryzyko polegające na zautonomizowaniu motywu, który w spektaklu musi przecież „współpracować” - jak słusznie zauważył Hawryluk $\mathrm{z}$ innymi elementami scenicznego uniwersum. Ustanowiona $\mathrm{w}$ widowisku „przestrzenna przyległość” tych elementów - podkreśla Limon - „powoduje wzajemne przenikanie i zmianę waloru" ${ }^{37}$. Charakterystyczny dla dzieła teatralnego proces semiotyzacji - nadawania znaczeń wszystkiemu, co znajdzie się w planie gry - rodzi zatem konieczność uzgodnienia wielu, ze swej scenicznej natury mobilnych, znaków.

Wniosek wydaje się oczywisty. Woda w teatrze niewątpliwie daje możliwość tworzenia niezwykle spektakularnych, wręcz glamourowych obrazów, lecz jednocześnie wymusza scenograficzną ascezę. Immanentna widowiskowość, oferująca całe instrumentarium niemal "gotowych” efektów, wymaga ogromnej inscenizacyjnej dyscypliny i wielkiej dramaturgicznej precyzji w konstruowaniu całości wizji scenicznej. Bo przecież, mówiąc metaforycznie, w teatrze - podobnie jak w naturze - wodny żywioł może bardzo łatwo wymknąć się spod kontroli.

doplynal_do_teatru_wielkiego_opery_narodowej_228378-2-1-d.html [dostęp: 17.02.17].

${ }^{35}$ J. Hawryluk, op. cit.

36 Zob. O. Pisarenko, op. cit.; H. Milewska, M.Ł. Gołębiowski, Wodochciejstwo, http://www.e-teatr.pl/pl/artykuly/206754.html [dostęp: 17.02.17]; B. Tumiłowicz, Aquapark na scenie, http://www.dziennikteatralny.pl/artykuly/aquapark-na-scenie. html [dostęp: 17.02.17].

37 J. Limon, Między niebem a sceną, Gdańsk 2001, s. 154. 
Ta zasada dotyczy nie tylko estetycznych, ale i semantycznych walorów wyjściowego tworzywa. Twórcy inscenizacji stosujących motywy akwatyczne - zwłaszcza w wersji „na bogato” - za każdym razem muszą dokonać trudnego wyboru, a następnie równie trudnego scenicznego przekładu kulturowych konotacji wody na znaki i symbole konkretnego spektaklu. Repertuar takich konotacji jest - jak dowodzą przywołane spektakle - wyjątkowo duży, lecz jest też naznaczony nieprzezwyciężalną ambiwalencją. Kulturowe tropy wody - rozpięte między biegunowo przeciwnymi sensami życiodajnej, oczyszczającej, wyzwalającej siły i niebezpiecznego, trudnego do okiełznania, śmiertelnego żywiołu, materialnej skończoności i metafizycznej, nieodgadnionej nieskończoności - czynią z niej tworzywo sceniczne naprawdę „wysokiego ryzyka”.

Na koniec warto przywołać jeszcze jedną - wydaje się, wcale nie najmniej istotną - refleksję. Woda w teatrze, tym razem w przeciwieństwie do wody $\mathrm{w}$ naturze, $\mathrm{z}$ czego zapewne zdają sobie sprawę twórcy teatralni, mimo wszystko może się po prostu opatrzyć.

Autorka oraz Redakcja dziękuja Autorkom $i$ Autorom fotografii oraz Teatrom za udostępnienie materiałów wizualnych i zgodę na ich bezpłatne wykorzystanie.

\section{Bibliografia}

Paloma Blanca, Nie ma historii, jest akcja [recenzja spektaklu Przyrzecze], http:// bydgoszcz.naszemiasto.pl/artykul/nie-ma-historii-jest-akcja-recenzja-spektaklu-przyrzecze,3158757,art,t,id,tm.html.

Anna S. Dębowska, Robia niesamowite rzeczy. Poznajcie ludzi Teatru Wielkiego $w$ Warszawie, http://warszawa.wyborcza.pl/warszawa/1,34889,16779121,Robia_niesamowite_rzeczy__Poznajcie_ludzi_Teatru_Wielkiego.html.

Anna S. Dębowska, Wielka ulewa w operze, http://www.e-teatr.pl/pl/artykuly/135257,druk.html.

«Fous de bassins» na zamknięcie festiwalu FETA w Gdańsku, 2011, http://www.institutfrancais.pl/pl/evs/fous-de-bassins-na-zamkniecie-festiwalu-feta-w-gdansku. Jacek Hawryluk, „Latajacy Holender” Trelińskiego. Trafiony, zatopiony, http://wyborcza.pl/1,75410,11372269,_Latajacy_Holender_Trelinskiego_Trafiony_zatopiony.html. 
Iga Herłazińska, Na początku i na końcu był chaos, http://www.teatrdlawas.pl/ recenzje/4959-na-poczatku-i-na-koncu-byl-chaos.

Monika Kostaszuk-Romanowska, Szekspir postindustrialny, [w:] Szekspir wśród znaków kultury polskiej, red. E. Łubieniewska, K. Latawiec, J. Waligóra, Wydawnictwo Naukowe Uniwersytetu Pedagogicznego, Kraków 2012.

Jerzy Limon, Między niebem a sceną, słowo/obraz terytoria, Gdańsk 2001.

Jerzy Limon, Piąty wymiar teatru, słowo/obraz terytoria, Gdańsk 2006. „Malta” rusza już XI raz, www.wprost.pl/kultura/15837/Malta-rusza-juz-XIraz.html.

Hanna Milewska, Maciej Łukasz Gołębiowski, Wodochciejstwo, http://www.e-teatr. $\mathrm{pl} / \mathrm{pl} /$ artykuly/206754.html.

Piotr Olkusz, Dlaczego nie po prostu?, http://teatralny.pl/recenzje/dlaczego-nie-po -prostu,1389.html.

Olgierd Pisarenko, Mokra robota. Latajacy Holender w Operze Narodowej, http://www. ruchmuzyczny.pl/PelnyArtykul.php?Id=2067.

Lidia Raś, „Latający Holender” dopłyną do Teatru Wielkiego Opery Narodowej, http://www.wiadomosci24.pl/artykul/latajacy_holender_doplynal_do_teatru_wielkiego_opery_narodowej_228378-2--1-d.html.

Agnieszka Serlikowska, Wodq̨ i dźwiękiem o...?, http://www.e-teatr.pl/pl/artykuly/138640,druk.html.

Spectacles sur l'eau, http://ilotopie.com/spectacles/?lang=fr.

Szymon Spichalski, Adamczyk stapa po wodzie, http://www.e-teatr.pl/pl/artykuly/139203.html.

Agata Tomasiewicz, Historia troszkę splamiona nieszczęściem, http://www.teatrdlawas.pl/recenzje/5283-historia-troszke-splamiona-nieszczesciem

Bronisław Tumiłowicz, Aquapark na scenie, http://www.dziennikteatralny.pl/artykuly/aquapark-na-scenie.html.

Đàm Vân Anh, W wodzie po kostki: wietnamski teatr lalek wodnych, http://kontynent-warszawa.pl/felietony/kulturalia/762-w-wodzie -po-kostki-wietnamski-teatr-lalek-wodnych.

Dorota Wyżyńska, Zalana scena, http://www.e-teatr.pl/pl/artykuly/18758.html. 


\section{Theatre on the Water. Aquatic Element in Contemporary Polish Theatre}

In view of theatrical performances, water is not only an important cultural trajectory, but also an attractive, though very special, stage material. The authoress draws attention to the ambivalent character of water as an element of the spectacle. Water identifies the very essence of theatricality, which consists of the constant oscillation between illusion and reality. The effect of real water - limited by technical restrictions and in effect artificial to some extent - has an unquestionable spectacle value. The authoress recalls selected performances whose creators have chosen large-scale solutions and introduced a large amount of water to the stage. In this way, she shows how they create the symbolic value of aqua motives, how they use their semantic and sensual potential in the process of translating the cultural connotations of water into signs and meanings of a particular show.

Keywords: water, theatre, spectacle, stage material 